\title{
Liquidity Planning Between Theory And Practice: An Overall Examination Of The GCC Banks During The Crisis Du Jour
}

\author{
Viviane Y. Naïmy, Notre Dame University, Lebanon
}

\begin{abstract}
After giving a rundown on banks' liquidity risk and management, and suggesting a simple model aiming at improving the efficiency of banks' liquidity management, this paper gauges the possible impact of the current crisis on the GCC ${ }^{l}$ economies, specifically the exposure of banks to asset write-downs, and rising costs of finance coupled with tight liquidity. The current outlook is exceptionally uncertain, with risks still weighing on the downside. The banking system appears adequately capitalized and highly profitable, but risks of a future deterioration of asset quality are still threatening the banks' financial situation. Fundamental measures should be taken in order to strengthen the banking supervision to contain the fiscal risks related to the emergency liquidity facilities.
\end{abstract}

Keywords: Banks' liquidity management, liquidity risk, GCC Banks, financial crisis, GCC monetary policy.

\section{INTRODUCTION}

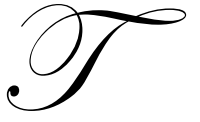

he recent banks bankruptcies are mainly due to a general liquidity and credit crunch that affected various asset classes such as money market funds, credit default swaps and other OTC derivatives. In fact, the US subprime crisis of 2007 has developed into a full-blown international financial crisis with serious consequences on the financial system of the GCC countries'. They are indeed facing liquidity troubles in their banking system and they have been negatively affected by the rising costs of funding. In 2007, financial markets showed considerable resilience; however, in 2008 the GCC stock markets ${ }^{2}$ have suffered much more than the ones in the US or other developed and emerging markets.

A key concern is that policies may be insufficient to prevent and stop the negative feedback between deteriorating financial conditions and weakening economies especially in the presence of limited public support for policy actions. Ensuring a durable economic recovery requires the respect of a set of priorities aiming at ensuring that financial institutions have access to liquidity, at identifying and dealing with distressed assets, and at recapitalizing weak but viable institutions and resolving failed institutions (IMF, 2009).

After giving a rundown on banks' liquidity risk and management, and suggesting a simple model aiming at improving the efficiency of banks' liquidity management, this paper gauges the possible impact of the current crisis on the GCC economies, specifically the exposure of banks to asset write-downs, and rising costs of finance coupled with tight liquidity.

The first section focuses on liquidity risk and its management while the second part suggests a simple single period model mainly designed to improve the efficiency of bank's liquidity management for the GCC

\footnotetext{
${ }^{1}$ Cooperation Council for the Arab States of the Gulf, a regional organization often referred to as the "Gulf Cooperation Council". Created on May 25, 1981, the 630-million-acre (2,500,000 km2) Council comprises the Persian Gulf states of Bahrain, Kuwait, Oman, Qatar, Saudi Arabia and the United Arab Emirates.

${ }^{2}$ In Dubai for example, stock prices have dropped more than $60 \%$ since January 2008.
} 
countries. The model covers an exhaustive comprehensive framework within which evaluating liquidity strategies becomes easy, subjective, and scientific. The last section gauges the major impacts of the current crisis on the GCC banks and mainly their exposure to increasing costs of funds and liquidity tightness.

\section{CONCEPTUAL FRAMEWORK}

\section{Review on Bank Liquidity Management, Needs, and Risks}

Oddly enough, given that liquidity management is one of the two principle risks facing banks, there are no international accords on liquidity management. It is all left to national regulators - although rumors have it that this may change with Basel III. Generally, each regulator follows its own path.

Essentially, a passive liquidity management implies that the bank does not have to take any action to generate cash inflows. This means from a pure liquidity perspective, that short term loans are attractive because they are self-liquidating and modern banks allocate various types of loans and generate cash inflows constituted of principal and interest paid on a regular nondiscretionary basis. In addition to maturing loans, banks hold investment securities such as government bills, notes, and bonds that pay interest and mature on a regular basis thus providing another nondiscretionary source of funds aiming at meeting liquidity needs (Luckett D., 1980).

In contrast to this anticipated inflow of funds, the active liquidity management involves a speed up process of funds inflow through selling or lending assets (e.g., repurchase agreements) or simply calling loans. The better and safer mean to generate liquidity is to sell or securitize loans since calling them can jeopardize the customer relationships. An asset conversion or shiftability approach to liquidity management was accepted in the US after World War II. When passive asset conversions are used to meet a bank's expected cash outflows, the strategy is known as the anticipated income theory. It is a development of the asset conversion method that focuses on expected cash flows of both the bank and the borrower which led in the 1950s to the expansion of amortized loans and staggered investment maturities.

In the early 1960s banks started to focus on liabilities for liquidity, and profitable broadening of their balance sheets especially after the introduction of the negotiable certificate of deposit (CD). This approach is known as liability management (LM) where banks acquire deposit and nondeposit debt, called purchased funds, in local and international money markets. LM depends on a bank's reputation creditworthiness and gives bankers greater flexibility in managing their balance sheets. It has obliged bankers to think about the coordinated financial management of their balance sheets - asset-liability management (ALM) or risk management (RM). Liquidity management has evolved to the current state of ALM by progressing through six different stages: commercial loan theory or real-bills doctrine -1920 s and earlier-, asset conversion or shiftability approach - post-World War II through 1940s-, anticipated income theory (1950s), LM - late 1960s and early 1970s-, ALM and securitization - mid 1970s to mid 1990s-, and risk management -mid-1990s to present- (Koch T. and Macdonald S. , 2003).

Banks must be prepared to meet deposit withdrawals and borrowing activities on a daily, and sometimes hourly, basis (Cates D. (1990)). If the expected inflows are not adequate enough to cover expected uses of funds (new loans, credit draws, and deposit withdrawals), then the bank faces a liquidity need. The bigger the size of the discrepancy between the sources and uses of funds the harder the problem of liquidity needs. Therefore, banks are expected to either draw down their inventories of stored liquidity at a rate faster than they had planned or purchase funds in the marketplace at a greater volume than planned or both.

The risks of liquidity management have price, quantity and reputation effects (Holmström B. and Tirole J., 2000). The primary risk of active liquidity management arises from interest rate risk. Price or interest rate risk focuses on the price at which assets can be sold and the rate at which liabilities can be acquired. The quantity risk focuses on the possibility of selling the existing assets and on the availability of funds at any cost in the marketplace. Maintaining a sound reputation is a must for a bank practicing in an active liability management. Large banks are subject to market discipline. If they don't maintain their creditworthiness, they have to pay up for funds or funds will not be available. In extreme cases, funds simply will not be supplied at any price. It is how financial markets are supposed to work, and it is called market discipline. A lack of confidence in a bank can be destructive when it 
occurs in the money market. Issuing subordinated notes and debentures on a regular basis, is a good strategy to get market discipline. The pricing of this debt instrument constitutes a signal of the issuer riskiness and another source of market discipline.

\section{Liquidity versus Profitability}

There is a short-run trade-off between liquidity and profitability. The more liquid a bank is, the lower are its return on equity and return on assets, ceteris paribus. Both asset and liability contribute to this relationship. Asset liquidity is influenced by the composition and maturity of funds. By their nature, liquid assets have minimal amounts of interest rate risk and credit risk, which limit the reward they generate for bearing risk. Specifically, short-term assets are less sensitive to interest rates. A further consideration is the normal upward shape of the yield curve with short-term rates lower than long-term ones. The exception to this situation occurs when the yield curve is negatively slopped. Under this structure, short-term investors get the best of both worlds in the form of low risk and high return. Historically, however, since the normal slope of the yield curve has been positive, this phenomenon has been a short-lived one. A liquid asset is characterized by a well-established market where their market and book values show little divergence. In fact, sellers of such liquid assets, notably interbank deposits, treasury securities, and Federal funds sold (including repurchase agreement), face little or no capital loss.

In terms of liability liquidity, banks with good asset quality and high equity capital have easier access to purchased funds and pay lower interest rates and generally report lower returns in the short run. Promised yields on loans and securities increase with the perceived default risk of the underlying issuer. Banks with greater equity financing exhibit lower equity multipliers and thus generate lower returns on equity, even with identical returns on assets. These banks can borrow funds cheaper because a greater portion of their assets have to be in default before they might fail.

Liquidity planning concentrates on guaranteeing that immediately available funds are obtainable at the lowest cost. Management must determine whether liquidity and default risk premiums more than compensate for additional risk on longer-term and lower-quality bank investments. If management is successful, long-term earnings will exceed peer banks' earnings, as will bank capital and overall liquidity (Cooper R. and Thomas R., 1998).

\section{THE MODEL}

The purpose of this model is to provide the GCC banks with a simple framework that facilitates their liquidity strategies' process. The model can be simply applied without sophistication in the calculation. It is specifically designed for countries where banks regulations are simple and financial products held with banks are straightforward and far from complexity. Not all the variables are applicable to all banks. The bank can select the applicable variables and run the model in order to enjoy a better and efficient liquidity planning. This model is mainly based on the works of B. Fielitz and T. Loeffler (1979) and J. Stein (1998).

Liquidity is viewed as supporting many other functions of a bank, therefore significant returns might be realized by actively managing liquidity for profit. There are many constraints that limit the ability of the liquidity manager to maximize profit such as accounting and regulatory restrictions and risk and return preferences of the bank managers. The model will take these constraints into consideration and is a single period model.

\section{Definition of Variables}

Table 1 depicts the variables classified as sources or uses of funds. The variables are defined as the purchase or sale of a liquid asset or as the issuance of a liquidity liability and are marked out by maturity, type of issue, etc. The liquidity variables are assumed to be continuous. The relationships among variables are supposed to be linear. The model constraints are designed to respect the linearity assumption. If desired and when applicable, many other variables can be incorporated into the model besides the below listed ones. 
Table1: The Liquidity Variables

\begin{tabular}{|c|c|c|c|}
\hline Variable & Instrument & $\begin{array}{c}\text { Uses of Funds (UF), Sources } \\
\text { of Funds (SF) }\end{array}$ & $\begin{array}{l}\text { Type: Asset (A) or } \\
\text { Liability (L) }\end{array}$ \\
\hline $\mathcal{X}_{1 j}\left(\mathrm{j}=1, \ldots, \mathrm{m}_{1}\right)$ & Treasury Securities & UF & $\mathrm{A}$ \\
\hline$x_{2 j}\left(\mathrm{j}=1, \ldots, \mathrm{m}_{2}\right)$ & Agency Securities & UF & A \\
\hline $\mathcal{X}_{3 j}\left(\mathrm{j}=1, \ldots, \mathrm{m}_{3}\right)$ & Muni Securities & UF & $\mathrm{A}$ \\
\hline$x_{4 j}\left(\mathrm{j}=1, \ldots, \mathrm{m}_{4}\right)$ & Project Notes & UF & A \\
\hline$x_{5 j}\left(\mathrm{j}=1, \ldots, \mathrm{m}_{5}\right)$ & CD-Bank & UF & $\mathrm{A}$ \\
\hline$x_{6 j}\left(\mathrm{j}=1, \ldots, \mathrm{m}_{6}\right)$ & Reverse Repo & UF & $\mathrm{A}$ \\
\hline$x_{7}$ & Federal Funds sold & UF & A \\
\hline $\mathcal{Y}_{1 k}\left(\mathrm{k}=1, \ldots, \mathrm{n}_{1}\right)$ & Treasury Securities & SF & A \\
\hline $\mathcal{Y}_{2 k}\left(\mathrm{k}=1, \ldots, \mathrm{n}_{2}\right)$ & Agency Securities & SF & $\mathrm{A}$ \\
\hline $\mathcal{Y}_{3 k}\left(\mathrm{k}=1, \ldots, \mathrm{n}_{3}\right)$ & Muni Securities & SF & A \\
\hline $\mathcal{Y}_{4 k}\left(\mathrm{k}=1, \ldots, \mathrm{n}_{4}\right)$ & Project Notes & SF & $\mathrm{A}$ \\
\hline $\mathcal{Y}_{5 k}\left(\mathrm{k}=1, \ldots, \mathrm{n}_{5}\right)$ & CD-Bank & SF & $\mathrm{A}$ \\
\hline$y_{6 k}\left(\mathrm{k}=1, \ldots, \mathrm{n}_{6}\right)$ & Repo & SF & $\mathrm{L}$ \\
\hline$y_{7}$ & Federal Funds bought & SF & $\mathrm{L}$ \\
\hline$y_{8 k}\left(\mathrm{k}=1, \ldots, \mathrm{n}_{7}\right)$ & CD-Public Money & SF & $\mathrm{L}$ \\
\hline $\mathcal{Y}_{9 k}\left(\mathrm{k}=1, \ldots, \mathrm{n}_{8}\right)$ & CD-Money Market & SF & $\mathrm{L}$ \\
\hline$y_{10}$ & Discount window borrowings & SF & $\mathrm{L}$ \\
\hline
\end{tabular}

$x_{i j}$ and $y_{i k}$ values represent dollar amounts;

$i$ refers to the type of liquidity variables;

$j$ and $k$ refer to particular issues or options available under each general category such as number of issues, risk, maturity, coupon rate, etc.

The purchase of a liquid asset or the sale of a liquidity liability are reflected according to their current market value.

The sale of a liquid asset is reflected according to its book value in order to simplify the calculation of the objective function coefficient and the formulation of the securities profit/loss equation. 
The management of the liquidity variables has the objective to maximize the net profit equation which is expressed as follow:

$\operatorname{Max} \mathrm{P}=\sum_{i} \sum_{j} b_{i j} x_{i j}-\sum_{i} \sum_{k} b_{i k} x_{i k}$

$\mathrm{b}_{\mathrm{i}(\mathrm{j} \text { or } \mathrm{k})}{ }^{3}$ represents the current after-tax yields to maturity (YTMs) of assets and liabilities and are calculated using Fisher's algorithm. Yields are stated as annual compound rates.

The closely related market alternative yields can be used as coefficients in the objective profit equation. These coefficients vary by sign and by method of computation. Adjustments to $b_{i j}$ or k) are made depending on whether the current price (or book value) is at discount, equal to, or at a premium with respect to the face value. The algorithm model selects the combination of liquid assets and liquidity liabilities that maximizes the net profit to the bank (J. Stein, 1998).

\section{Institutional and Management Constraints}

Legal, accounting, or market reasons constitute the major institutional constraints that apply to all commercial banks. Quantifying these constraints leads to consider the activity level of the bank, the collateral and the cash flow constraints.

Selling more of an asset than is held is not allowed. This is called the activity constraints which are related to the assets representing the sources of funds.

(2) $y_{1 k} \leq T_{y 1 k}, \mathrm{k}=1, \ldots, \mathrm{n} 1$, (3) $y_{2 k} \leq T_{y 2 k}, \mathrm{k}=1, \ldots, \mathrm{n} 2,(4), y_{3 k} \leq T_{y 3 k}, \mathrm{k}=1, \ldots, \mathrm{n} 3$, (5) $y_{4 k} \leq T_{y 4 k}$, $\mathrm{k}=1, \ldots, \mathrm{n} 4,(6) y_{5 k} \leq T_{y 5 k}, \mathrm{k}=1, \ldots, \mathrm{n} 5$

where:

$n_{i}$ are the total number of issues of each type of variable available for sale,

$T_{y i k}$ represents the book value of each variable held.

Banks are also required to hold collateral for the acquisition of certain types of liabilities ${ }^{4}$. The constraint can be written as follow:

$\sum_{j} x_{3 j}+\sum_{j} x_{4 j}-\sum_{k} y_{3 k}-\sum_{k} y_{4 k}-\sum_{k} y_{8 k} \geq(\mathrm{CD}-$ Public Money $)-T_{y 3 k}-T_{y 4 k}$

The excess of CD-Public Money is the amount of time deposits held by bank and not maturing during the decision horizon.

The cash flow constraint is constituted of the difference between the positive cash flow generated from certain variables (sources of funds) and the outflow generated from other variables (uses of funds). Basically, inflows include the sale of assets or the issuance of liabilities $\left(\mathrm{y}_{\mathrm{ik}}\right)$. Outflows are due to the purchase of assets $\left(\mathrm{x}_{\mathrm{ij}}\right)$. Therefore the constraint becomes:

\footnotetext{
${ }^{3} b_{\mathrm{ij}}$ values are positive because they represent positive contributions to profit (received yield). However, the sale of assets or the issuance of liabilities (source of funds) represent negative contributions to the profit because of yield forgone or expenses incurred, therefore $b_{i k}$ sign is negative

${ }^{4}$ Federal Reserve Discount window borrowings, state and muni deposits, etc.
} 
- $\sum_{i} \sum_{j} a_{i j} x_{i j}+\sum_{i} \sum_{k} a_{i k} y_{i k} \geq \mathrm{C}-\mathrm{M}$

When $\mathrm{C}>0$, it is defined as external cash flow ${ }^{5}$ and when $\mathrm{C}<0$ it represents an inflow.

$\mathrm{M}$ is the net maturing amount of liquidity.

$\mathrm{a}_{\mathrm{i}(\mathrm{j} \text { or } \mathrm{k})}$ are adjustment values of book values to actual cash flow amounts.

$\mathrm{a}_{\mathrm{i}(\mathrm{j} \text { or } \mathrm{k})}=$ Current Price/Book Value $-($ Current Price-Book Value $)\left(\right.$ Tax Rate $\left.{ }^{6}\right) /$ Book Value

- Reserve Requirement (\%) \pm Accrued Interest (1- Tax Rate)/Book Value

The model provides sufficient cash flow to meet obligations as long as $\mathrm{c} \geq \mathrm{C}-\mathrm{M}$ where $\mathrm{c}$ equal the cash flow resulting from the purchase or sale of liquid assets or the issuance of liquidity liabilities as illustrated in equation 8 .

On the other hand, management constraints reflect exclusive policy restrictions of banks (Sharpe S., 1995). They are systematically revised in consistency with risk/return preferences, expected yields and profits, etc. These constraints include the portfolio structure, the liquidity capability, the maturity, and the securities gain or loss. Portfolio structure constraints are limitations preventing excessive dependence on certain instruments. The quantitative shape of these constraints can be multiple. Lower and upper bounds on the value of each variable can be fixed or a percentage portfolio composition constraints may also be formulated. Many alterations of this straightforward formulation are feasible. Liquidity capability constraint is to insure that the bank maintains adequate liquid assets for projected unanticipated deposit withdrawals or credit demands. It is related to the assets of the bank. The net liquid assets should not be less than a percentage of total assets. Maturity constraints can be easily manipulated by the liquidity manager to either lengthen or shorten the average maturity of his/her portfolio as per his/her subjective evaluation of future economic conditions (Mueller H., 1998).

\section{DIRECT AND INDIRECT EFFECTS OF THE FINANCIAL CRISIS ON GCC BANKS' LIQUIDITY}

The global financial system remains under severe stress as the crisis expanded to involve households, corporations, and the banking sectors. Commercial banks are facing serious pressure on their balance sheets as asset values continue to degrade weakening their capital adequacy and discouraging fresh lending. Therefore, credit growth is slowing, not to say turning negative, adding even more downward pressure on economic activity. Interbank liquidity has dried up and refinancing costs have increased dramatically. More than 2 trillion US dollars in write-downs had occurred by the end of March 2009.

In 2007, the GCC countries registered USD 1.87 trillion in foreign assets, of which 58\% are held in USD. These countries revealed serious concerns about their assets depreciation. Moreover, their financial markets have been dramatically affected by the rising costs of borrowing and the scarcity of credit facilities. Quantifying the exposure of commercial banks to the crisis is quite difficult because of the lack of transparency. Table 2 depicts the write-downs details for few GCC banks and financial institutions with more exposure expected to emerge with time.

Obviously, the investment rules in the GCC countries for commercial banks have successfully controlled and restricted the trade in sophisticated financial products which was very beneficial to the global exposure of some banks. On the other side, Sovereign Wealth Funds (SWFs) were managing most of the GCC assets such as Kuwait Investment Authority (KIA), Abu Dhabi Investment Authority (ADIA) and were investing in sophisticated products and financial risky assets. The volume and structure of these portfolios are not publicly available. However, an estimation of at least 50\% investment in equity leads to a dramatic exposure in the current stock market crisis despite the diversification rules and its implications. In addition, the huge overseas investments of many GCC companies have severely affected the foreign position of these countries, namely the USD 11.6 billon purchase amount of $\mathrm{SABIC}^{7}$ of GE plastics or the USD 1 billion investment amount of Emaar in John Laing Homes ${ }^{8}$.

\footnotetext{
${ }^{5}$ Projected credit demand, deposit withdrawals, etc.

${ }^{6}$ Tax effects are considered on a period-to-period basis.

${ }^{7}$ Saudi Basic Industries Corporation.
} 
Table2: Write-Downs Details for Few GCC Financial Institutions

\begin{tabular}{|c|c|c|}
\hline Bank / Financial institution & Exposure in USD million & Clarification \\
\hline Bahrain's Arab Banking Corporation & $1,200^{9}$ & \\
\hline Gulf International Bank & $1000^{10}$ & $\begin{array}{l}\text { The bank rating was downgraded by } \\
\text { Moody's. This was attributable to the bank's } \\
\text { holdings of MBS. }\end{array}$ \\
\hline Abu Dhabi Commercial Bank & $272^{11}$ & $\begin{array}{l}\text { The bank is suing Morgan Stanley and many } \\
\text { other international banks for distorted } \\
\text { guidance. }\end{array}$ \\
\hline Gulf Investment Corporation & $450^{12}$ & \\
\hline UAE Banks & & $\begin{array}{l}\text { No public announcement by banks about } \\
\text { further exposure }{ }^{13} \text { has been published. }\end{array}$ \\
\hline Saudi Banks & & $\begin{array}{l}\text { The Saudi Arabian Monetary Authority } \\
\text { (SAMA) declares the absence of exposure. }\end{array}$ \\
\hline Bahrain Banks & & $\begin{array}{l}\text { The Central Bank }{ }^{14} \text { of Bahrain declares the } \\
\text { exposure of banks however without giving } \\
\text { any details. }\end{array}$ \\
\hline Tawuniyya Saudi Insurance Company & $75 \%$ of its total market Value ${ }^{15}$ & $\begin{array}{l}\text { This dramatic decline is mainly due to the } \\
\text { high exposure with AIG. }\end{array}$ \\
\hline
\end{tabular}

Measuring the direct effect of the crisis on the GCC banks exposure cannot be accurate as previously mentioned. It is rather based on the collection of some piece of information as well as on subjective estimation. Therefore, applying the liquidity planning model as previously elucidated seems impossible. To this end, we will analyze the overall indirect impact of the crisis on the GCC banks liquidity.

\section{GCC Dried-Up Liquidity}

GCC banks are facing tight liquidity. This can be attributable to the following main factors:

1. Negative real interest rates: one of the flagrant macroeconomic consequences of the crisis in the GCC countries is the negative real interest rate level due to the high inflation and low nominal rates. Evidently, such result cannot encourage savings. Inflation has been steadily rising due to increases in housing costs and other prices as shown is figure 1 .

\footnotetext{
${ }^{8}$ Second largest privately held home builder in the US.

${ }^{9}$ MEED, Middle East Business Intelligence, 2008. "Arab Banking Corp announces further Subprime Losses."

http://www.meed.com/news/index.html

${ }^{10}$ Financial Times, 2008. "Gulf Bank raises \$ 1 billion to cover Subprime write-downs".

${ }^{11}$ Reuters News.

${ }^{12}$ MEED, Middle East Business Intelligence, April 2009.

${ }^{13}$ Such exposure includes bank bonds, derivative trades (credit default swaps) and structured investment products guaranteed by US investment banks.

${ }_{15}^{14}$ MEED, Middle East Business Intelligence, December 2008.

15 www.tadawul.com
} 
Figure 1: UAE and GCC Inflation since 2003

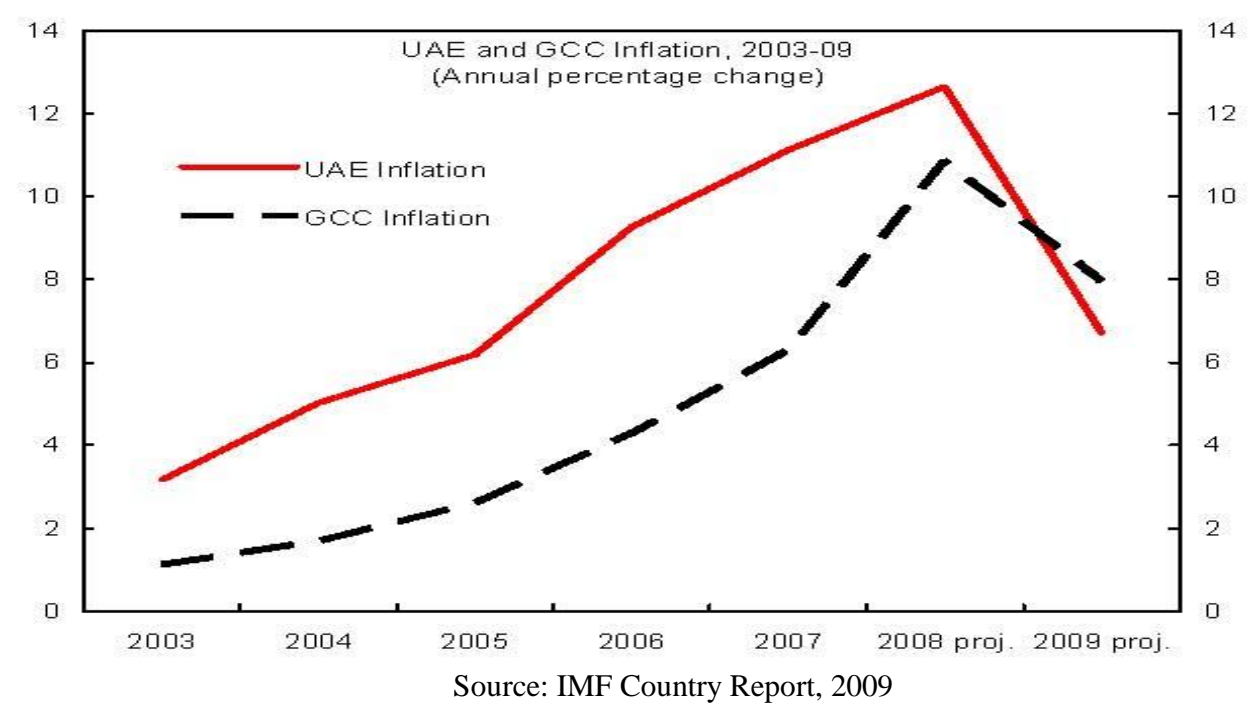

2. Relative appreciation of the US dollar: capital inflows to the GCC countries driven by expectations of a revaluation of the dirham vis-à-vis the U.S. dollar largely reversed over the summer of 2008; currency futures indicate that markets no longer doubt the peg.

Figure 2: Speculation on a Revaluation of the Dirham

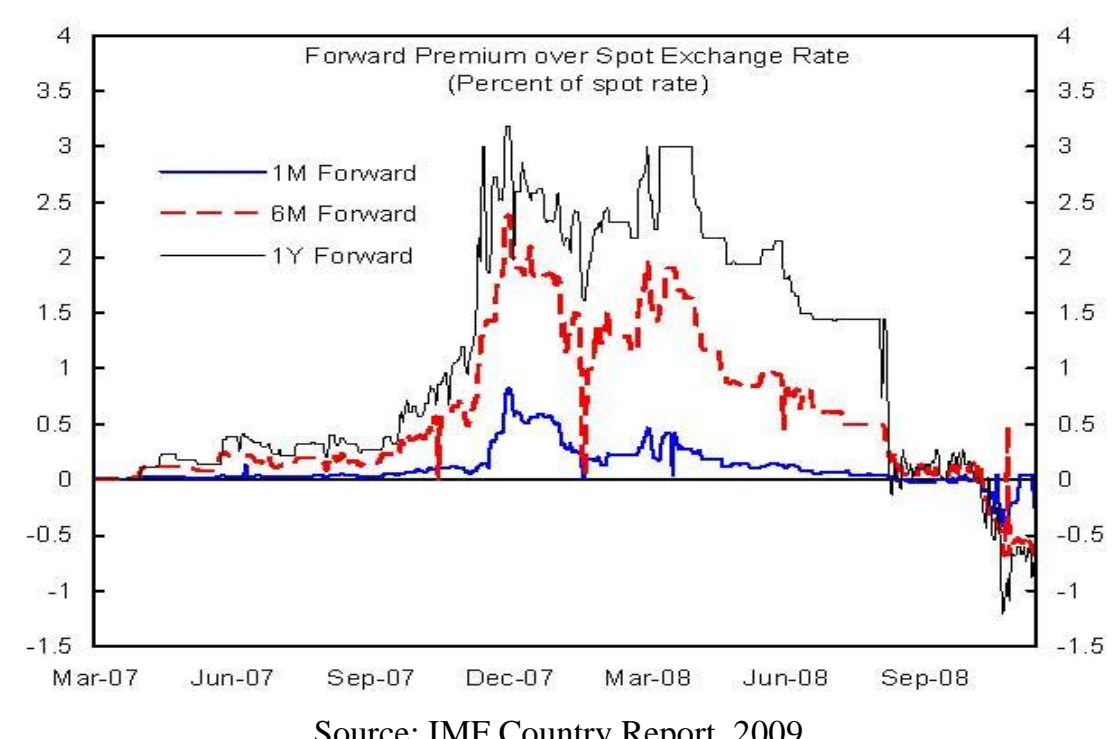

Source: IMF Country Report, 2009

3. International investments: huge amounts have been invested inside and outside the GCC countries and have been frozen because of the devaluation.

4. A dramatic decrease in the net foreign direct investment as shown in figure 3. 
Figure 3: GCC FDI since 2004

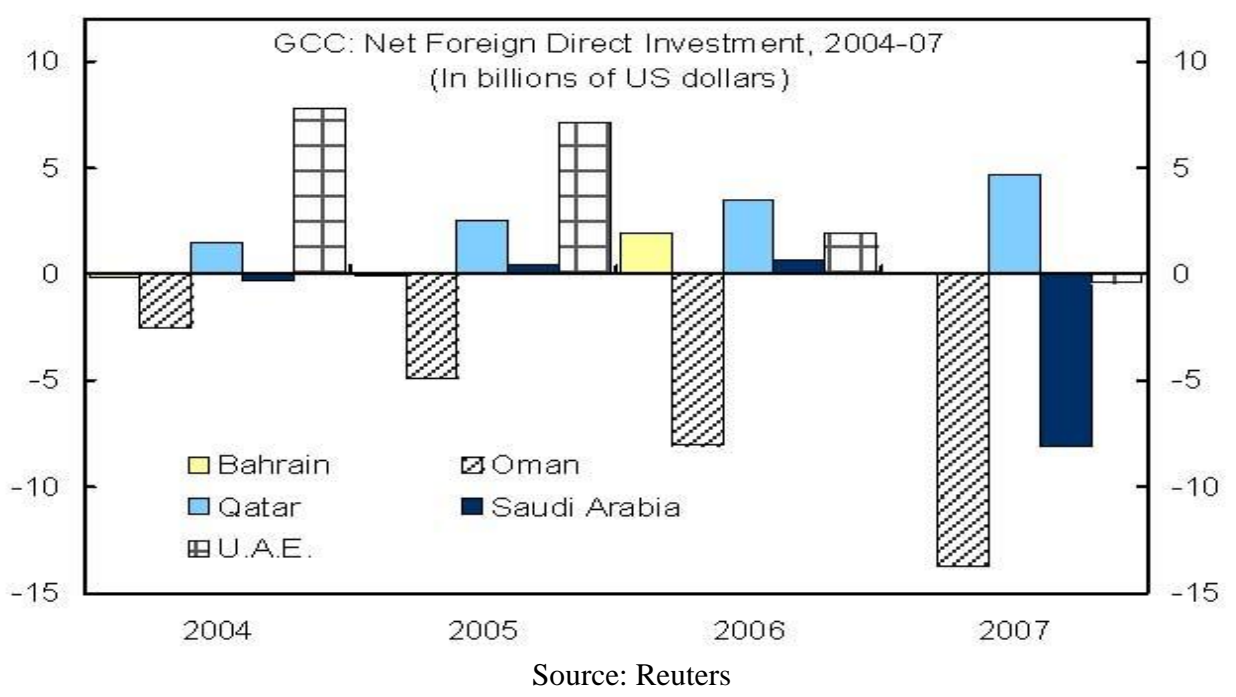

In addition to the tight liquidity, the galloping cost of funds has blocked growth hopes (figure 4).

Figure 4: The GCC Real Non-Oil GDP Growth since 2003

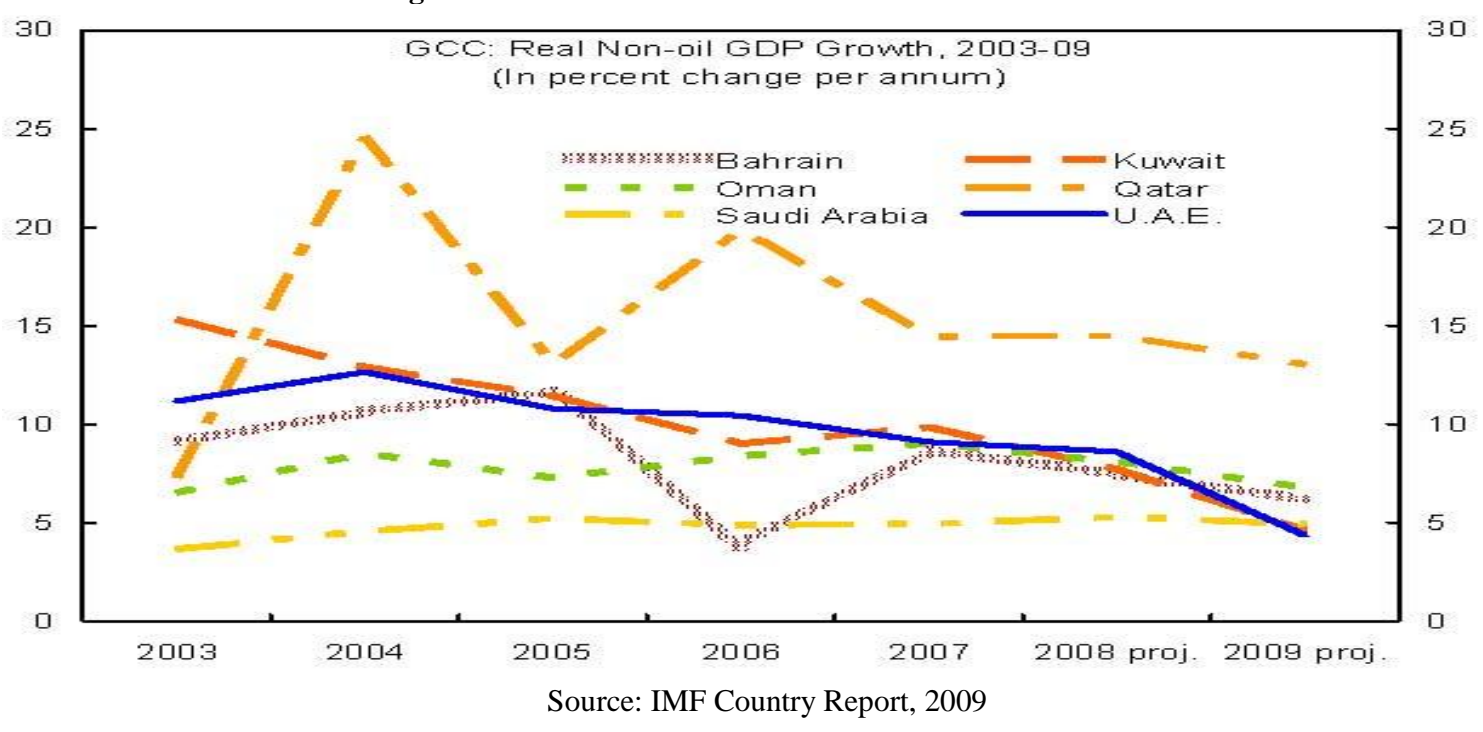

The GCC banks need to refinance themselves through the capital markets at very high prices. This increase is illustrated through the following indicators:

1. The GCC corporate bonds spreads increased from 145 in 2007 to over 500 basis points above the LIBOR and the EIBOR. Specifically, the Emirates interbank rate more than doubled since June 2008. 
Figure 5: HSBC/DIFX GCC Conventional Corporate US Dollar Bond Index (GCCI ${ }^{16}$ )

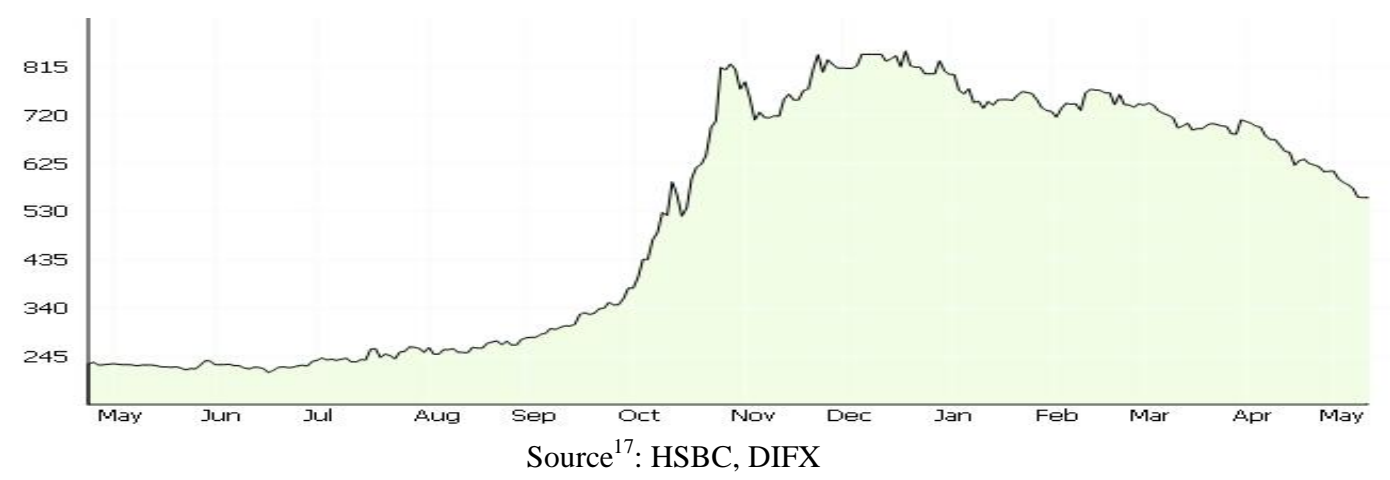

2. The deterioration of Dubai-related credit. Dubai has the largest market share of the GCC bond market because of the huge borrowed amounts for its projects.

3. The Credit Default Swap (CDS) market is alarming especially when it comes to financing all the already embarked projects.

4. The mismatching between long term and short term funds increase the burden on the already tensed capital markets.

5. The syndicated loan market in the GCC is now handicapped. In fact, international banks that constitute the leading financing feeders ${ }^{18}$ are indisposed and incapable to extend credit facilities since they are facing themselves severe liquidity constraints in their own markets.

As a consequence of the above facts, loans faced a drastic drawdown. In the third quarter of 2008, the borrowed amounts in the Middle East dropped down to USD 90 billion from USD 110 billion in 2007. Half of the outstanding GCC debt in foreign and local currencies (USD 42 billion in 2009) is counted on the UAE liabilities. This debt will be financed via bonds issuance and yet the issuance conditions are continuously worsening given the spreads' trend on GCC bonds (figure 5).

\section{GCC Monetary Policy Measures}

To preempt spillovers from the global turmoil and address continued liquidity pressures in the banking system, the GCC authorities took a set of measures, not common in each country, and mainly aiming at preserving financial stability through various emergency liquidity facilities, guarantee of deposits, and a strengthening of banking supervision. This was done at the expense of inflation.

The Kuwaiti Central bank reduced its discount rate by $25 \%$ and injected liquidity in the money market to encourage the credit activity by reducing the lending rates. Since March 2008, the UAE Central Bank has taken several steps to address a drying-up of liquidity following an outflow of foreign deposits. In March 2008, a facility allowing banks to borrow against their holdings of central bank certificates of deposit (CDs) replaced foreign borrowing as a key source of funding. In September, the central bank established an additional USD 13.6 billion facility to offset shortfalls in other bank funding sources, allowing banks to tap their reserve requirements at a penalty rate of 1.5 percent above the repo rate. In October 2008, the government declared a blanket guarantee of deposits and inter-bank lending for three years, and put in place an additional USD 19.1 billion emergency liquidity support fund (in the form of interest-yielding government deposits) to provide banks with long-term funding relief. The cost was in fact too high and the EIBOR continued to rise. The Abu Dhabi government provided some of its banks and corporates with deposits and direct budgetary loans, respectively. On the other hand, the Saudi Arabian

\footnotetext{
${ }^{16}$ The GCCI is designed as a replicable benchmark tracking the return of an emerging GCC Conventional Corporate bond portfolio. It consists of USD/ GBP/ JPY/ EUR-denominated fixed/ floating rate vanilla conventional bonds.

${ }^{17} \mathrm{http} / / /$ www.difxhsbcindices.com/Indices.aspx?HSBCCode=HXCGCXX

${ }_{18}$ Because of their very large capitalization
} 
Monetary Agency, SAMA ${ }^{19}$, cut its repo rate to $2 \%$ on January 19, 2009, the lowest rate since 2004.

\section{DISCUSSION, EXPECTATIONS AND RECOMMENDATIONS}

The current outlook is exceptionally uncertain, with risks still weighing on the downside. The GCC countries have been adversely affected by the turmoil in global financial markets, as evident in a widening of sovereign risk spreads and a sharp downturn in stock markets - most pronounced for real estate companies. The banking system appears adequately capitalized and highly profitable, but risks of a future deterioration of asset quality are still threatening their financial situation. Despite the high average capital adequacy ratio of banks that stood at $13 \%$ in 2008 (above the regulatory minimum of 10\%), the incredible fast pace of growth of consumer and real estate loans along with the uncertain outlook for asset prices has raised the risk of a future increase in nonperforming loans (NPLs). Recent capital outflows and growing concerns about counterparty risk have seriously affected the functioning of the GCC interbank market.

Growth is expected to slow significantly in 2009 on the back of the worsened global outlook, before gradually recovering during 2010-13. This reflects a slower expansion in the non-oil sector, particularly in tourism and constructions, especially that domestic and foreign demand have already considerably weakened. Inflation is expected to decelerate to about $4 \%$ by 2012 as demand pressures and international commodity price inflation ease. Foreign financing for ongoing and planned investment projects may be scaled back further, and the refinancing of corporates' foreign debt could become more complicated. Corporates as well as households will likely scale down investment plans for the next few years but demand for domestic financing will increase-if only to complete ongoing projects - at a time when domestic banks are already under stress. Such developments could trigger a correction in the real estate market, and thereby a deterioration of asset quality in the financial system.

In the light of our model and of the current liquidity situation of the GCC banks, we recommend some fundamental measures to be taken. Such procedures aim at strengthening the banking supervision to contain the fiscal risks related to the emergency liquidity facilities. This involves:

1. Scientifically assessing banks' asset portfolios with a focus on real estate loans, and review of the loan's classification and provision regulations in order to obtain sharper measures of exposures and risks;

2. Increasing the frequency of regular reporting by banks of liquidity indicators for a better liquidity planning and easy implementation of a scientific model similar to that described in this paper;

3. Strengthening the central bank's power to take prompt corrective measures;

4. Stiffening penalties for violation of laws and regulations or unsafe practices;

5. $\quad$ Providing better legal protection for supervisors.

On the other hand, we recommend the introduction of money market instruments, notably through the issuance of short-term government paper. Regular issuance of government bills could also reduce government reliance on funding from the various sovereign wealth funds (SWFs) in an economic downturn and in times of low oil prices.

\section{AUTHOR INFORMATION}

Viviane Youssef Naimy is presently professor of Finance at Notre Dame University. She has published articles in a number of professional journals in the area of risk management, investment, corporate finance and financial modelling. Her current interests are in spreadsheet modelling, ALM, and derivatives. She was recognized for superior teaching; she received more than seven international awards in recognition of Excellence in Research. She worked for several banks and launched the first Mutual Fund in Lebanon and has structured one of the largest syndicated loans. For the World Bank, she assessed the feasibility of introducing the securitization process in the banking sector in Lebanon.

${ }^{19}$ http://www.sama.gov.sa/Pages/Home.aspx 


\section{REFERENCES}

1. Bernanke B. and Blinder A. (1988), "Credit Money and Aggregate Demand." American Economic Review, Papers and Proceedings, Vol.78, pp. 435-439.

2. $\quad$ Cates D. (1990), "Liquidity Lessons for the 1990's." Bank Management, April, pp.20-24.

3. Cooper R. and Thomas R. (1998), "Bank Runs: Liquidity Costs and Investment Distortions." Journal of Monterey Economics, Vol. 41, No.1, pp. 27-38.

4. $\quad$ Fama E., (1985), "What's different About Banks.” Journal of Monetary Economics, Vol. 15, pp. 29-39.

5. $\quad$ Fielitz B. and Loeffler T. (1979), "A linear Programming Model for Bank Liquidity Management." Journal of financial Management, Vol 8, No. 3, pp.41-50.

6. $\quad$ Harrington R. (1987), "Asset Liability Management by Banks.” OECD.

7. Holmström B. and Tirole J. (2000), "Liquidity and Risk Management." Journal of Money, Credit and Banking, Vol.32, No.3, Par 1, pp. 295-319.

8. IMF, 2009: World Economic and Financial Surveys

9. Kane E. and Burton M.(1965), "Bank Portfolio Allocation, Deposit Variability, and the Availability Doctrine." Quarterly Journal of Economics, February, pp 113-134.

10. Keeley M. (1990), "Deposit Insurance, Risk, and Market Power in Banking." American Economic Review, Vol.80, pp.1183-1200.

11. Koch T. and Macdonald S. (2003), Bank Management. Thomson- South-Western, pp. 505-532.

12. Luckett D. (1980), “Approaches to Bank Liquidity Management." Economic Review, Federal Reserve Bank of Kansas City, March, pp. 11-27.

13. Mueller H. (1998), "Bank Liquidity, Short Memories \& Inescapable Basics.” Journal of Lending \& Credit Risk Management, Vol. 81; No1, pp. 61-69.

14. Naimy V. (2008), "Equity Mutual Funds Versus Market Performance: Illusion or Reality?.” The Journal of Business Review, Cambridge, Vol.11. No.1, pp.71-75.

15. Naimy V. (2008), "Tribulations of the Private Sector Between Financial Liberalization and Credit Rationing." The Journal of the National Defense, Vol.66. October, pp.47-89.

16. Rochet J.C. and Tirole J. (1996), "Interbank Lending and Systemic Risk." Journal of Money, Credit, and Banking, No. 28, pp. 733-62.

17. Sharpe S. (1995), "Bank Capitalization, Regulation, and the Credit Crunch: A Critical Review of the Research Findings." Board of Governors of the Federal Reserve System, Finance and Economics Discussion Series, 95/20.

18. Sinkey J. (2002), Commercial Bank Financial Management. Prentice Hall.

19. Stein J. (1998), "An Adverse-Selection Model of Bank Asset Liability Management with Implications for the Transmission of Monetary Policy." The RAND Journal of Economics, Vol. 29, No. 3, pp. 446-486.

20. Stylz R. (1996), "Rethinking Risk Management.” Journal of Applied Corporate Finance, No. 9, pp. 8-24. 